\title{
WORK STRESS, WORK-FAMILY CONFLICT, AND WORK PERFORMANCE WITH MEDIATION OF ORGANIZATIONAL SUPPORT AMONG PUBLIC AND PRIVATE EMPLOYEES: CASE OF COVID-19 PANDEMIC
}

\author{
Muhammad Hasmi \\ Abu Hassan Asaari ${ }^{1+}$ \\ Nasina Mat Desa ${ }^{2}$
}

\author{
${ }^{1,2}$ Management Section, School of Distance Education Universiti Sains \\ Malaysia, Malaysia. \\ ${ }^{2}$ Email:hasmi@usm.my
}

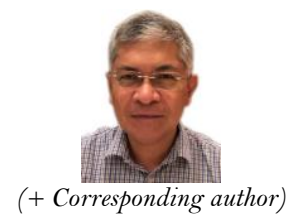

\section{Article History}

Received: 4 January 2021 Revised: 26 January 2021 Accepted: 2 February 2021 Published: 11 February 2021

\section{Keywords}

Work stress

Work-family conflict

Work performance

Organizational support

COVID-19

Malaysia.

\section{ABSTRACT}

The study investigates the employees' work stress, work-family conflict, and work performance with the mediation of organizational support during the COVID-19 pandemic in the country. The objectives of this study are to understand the relationship and investigate the impact of work stress and work-family conflict toward the employees' work performance. Furthermore, the study also examines the mediation effect of organizational support from the perspective of the employees' on their work stress and work-family conflict toward work performance. Self-administered questionnaires were distributed to the distance education students who are working in the public organizations and private organizations. A good and acceptable response rate of almost fifty three percent is obtained from the respondents. The data analyses such as reliability, correlations, and regression are done. In conclusion, the employees of the public and private organizations indicated that work stress and work-family conflict have a relationship and impacted their work performance. Meanwhile, the mediation of organizational support has a mediating effect between work stress and work-family conflict toward their work performance. Moreover, this study contributes to the existing literature on the mediation effects of organizational support that associated between the employees' work stress, work-family conflict, and work performance during the COVID-19 pandemic in Malaysia.

Contribution/ Originality: This study contributes to the existing literature on work stress, work-family conflict, and work performance with the mediation of organizational support during the COVID-19 pandemic.

\section{INTRODUCTION}

Work stress has been an issue to employees in their work-life. Apart from that they also encountered issues on their family conflicts along with their work stress. Thus, employees cannot escape themselves from the issues of work stress and work-family conflict. Moreover, various literature indicates that work stress and work-family conflict would affect their job performance. Furthermore, organizations would want their employees to contribute to their profits although their employees are facing with work stress and work-family conflict. For organizations to mitigate the employees' issues, the organizations make use of organizational support in support of their employees toward their work stress and work-family conflict. 
Recently, the nation has been facing with the COVID-19 pandemic throughout the country. Furthermore, the world population had faced the outbreak of the Novel Coronavirus as it was discovered in December 2019 (WHO, 2020). Moreover, the World Health Organization stated that:

"The evidence is highly suggestive that the outbreak is associated with exposures in one seafood market in Wuhan. The market was closed on 1 January 2020. At this stage, there is no infection among healthcare workers and no clear evidence of human to human transmission. The Chinese authorities continue their work of intensive surveillance and follow up measures, as well as further epidemiological investigations. Among the 41 confirmed cases, there has been one death. This death occurred in a patient with serious underlying medical conditions" (World Health Organization, 2020).

The pandemic had swept through all nations on the planet. As of today's date, the Worldometer (2020) website had reported the total number of the world population being infected was 19,257,726. On the encouraging side, the frontliners of COVID-19 had helped on the recovery of 12,357,662 patients. Unfortunately, a total of 717,687 patients had lost their lives to COVID-19.

In the context of Malaysia, the country had to faced and mitigated the spread of the pandemic COVID-19 throughout the country. The Ministry of Health $(\mathrm{MOH})$ had played an important role in mitigating the pandemic. Majority of the frontliners from various agencies and department had been mobilized throughout the country, such as doctors, nurses, hospital workers, police, and army forces. For the country, there were 9,038 patients had been infected with the pandemic. Meanwhile, a total of 8,713 patients had been recovered for their lives. Unfortunately, there were 125 deaths caused by the pandemic (Worldometer, 2020). Moreover, the government had taken serious measures in handling the COVID-19 pandemic by enforcing the nation's Movement Control Order (MCO) and Conditional Movement Control Order (CMCO). These orders had into effect from 17 March 2020 until 9 June 2020. Although the pandemic is still raging the country, the government had enforced Recovery Movement Control Order (RMCO) until 31 August 2020 with the noble intention to revive the nation's businesses and economies.

On the other hand, Malaysians had been affected in the form of psychologically and physically from the implementation of the nation's MCO, CMCO, and RMCO. The government had come up with various contingency and immediate in helping the individuals who were affected due to the minimal business activities of their companies and organizations. Thus, the PRIHATIN Economic Stimulus Package (ESP) was unveiled by the Prime Minister's Office of Malaysia (2020a). Moreover, Prime Minister Tan Sri Muhyiddin Yassin said:

"The measures introduced under the PRIHATIN ESP, Additional PRIHATIN, and the Short-term

Economic Recovery Plan (PENJANA) aims to address the impact from the COVID-19 crisis, while

simultaneously ensuring business continuity” (Prime Minister’s Office of Malaysia, 2020b).

Apart from the government's action plans, the nation cannot recover from the pandemic without the involvement of the individuals and organizations of Malaysia. Both parties must help the government to eradicate the pandemic COVID-19 and at the same time working together toward reviving the nation's businesses and economies. Undoubtedly, the employees of various organizations were affected in terms of mentally and financially. Thus, the support from the organizations toward their employees was crucial during the enforcement of the MCO and CMCO. Thus, the objective of this paper is to investigate the level of employees' work stress, work-family conflict, and work performance during the nation's MCO and CMCO. Moreover, the study also embarks on the mediation of organizational support from the employees' perspective as they felt the support from their organizations during the $\mathrm{MCO}$ and $\mathrm{CMCO}$ periods.

\section{LITERATURE REVIEW}

\subsection{Work Performance}

Work performance has been associated with employees' productivity. Moreover, the level of productivity is crucial to any organizations, especially on their profit and performance. Job performance is a very considerable 
factor influencing the profitability of any organization (Bevan, 2012). Performance is important for organizations as employees' performance leads to business success. This has been stated further that the employees' performance through the level of their productivity. Gitongu, Kingi, and Uzel (2016) stressed that employee performance is among the critical factors that contribute significantly to organizational success. Learning organizations play important role in enhancing employee performance through providing training and developments for their employees. Several types of research have been introducing various methods to evaluate organizational performance (Muda, Rafiki, \& Harahap, 2014; Prajogo, 2007; Wong \& Wong, 2007). Furthermore, Muda et al. (2014) examined the determinants for employee performance in Islamic Banks. They discovered that job stress, motivation, and communication variables simultaneously influence employees' performance.

In the other scholars also had studied the impact of motivation on employee performance and job satisfaction in IT Park (software house) sector of Peshawar, Pakistan (Amjad, Li, Huang, \& Ali, 2016). Their studies were in line with Landy (1985) and various other study work on the efficiency of employees indicated the fact that individuals are satisfied with their work will have greater work performance and thus greater job discharge than those who are not satisfied with their works. Meanwhile, in Jordan, a study explores the determinants of employees' performance in Jordanian industrial sector specifically exploring the impact of employees' satisfaction, management standards and training on employee's performance while exploring the mediating impact of employees' engagement (Dahkoul, 2018). He discovered that employees satisfaction, management standards and training are significant factors for employees' performance; having a significant impact on employee engagement that ultimately leads towards employees' performance. Ellinger, Ellinger, and Keller (2003); Dahkoul (2018) stated that employees' performance is the accumulates result of the skills, efforts and abilities of all the employees contributed in organizational improved productivity leading towards its goal achievement.

Moreover, management standards to evaluate employee performance also play a critical role in improving employee performance as they provide the picture of actual performance and its alignment with the benchmarks. If discrepancies found, then these standards help to bring the outputs again towards their required levels (Mackay, Cousins, Kell, Lee, \& McCaig, 2004). Employees performance also depends on their internal satisfaction towards their job. If employees are satisfied with their jobs as well as the organization than they are more keenly interested to perform well towards organizational goal achievement (Harter, Schmidt, \& Keyes, 2002).

Al-Omari and Okasheh (2017) stated that job performance is the result of an employee's motivation and ability, and how he/she adapts to the situational constraints and the uncongenial environment. This cannot be neglected as it leads to the behavioral disturbance; specifically referred to as the decrease in job performance. Their findings showed that the situational constraints are constituted of multiple variables such as noise, office furniture, ventilation and light. These are the major physical conditions that should gain more attention. It is suggested that employers should take initiatives to motivate employees by improving work environments. As employees are motivated, their job performance will increase, and they will achieve the desired outcomes and goals of the job.

\subsection{Work Stress}

Work stress or job stress can be defined as personal experience caused by pressure or demands on an individual, and impacts upon the individual's ability to cope or rather, his/her perception of that ability (Blaug, Kenyon, \& Lekhi, 2007). Moreover, job stress poses threat to an individual in their job environment (Muda et al., 2014). In some context, organizations required their employees to achieve a certain level of work, unfortunately, the employees were unable to cope with the given tasks. On the other hand, job stress has been known universally as a social problem (Mizuno, Yamada, Ishii, \& Tanaka, 2006) which has a combination of factors that disrupts the workers physically and psychologically $(\mathrm{Lu}, 1997)$ and affects their health care as a whole (Conwaya, Campaninia, Sartoria, Dottib, \& Costaa, 2008). 
Mai and Yen (2016) stated the effects of five working factors including work overload, role ambiguity \& role conflict, working relationship, career development, and working environment on job stress and employee job performance in six different industries in Vietnam. They discovered that these working factors had a significant and positive influence on job stress and in contrast, job stress had a negative influence on employee job performance. Moreover, they recommended that organizations should reduce job stress by reducing conflicts in a working relationship, career development, and working environment to improve employee job performance. Meanwhile, Kusuma (2018) studied the causes of the emergence of the stress, and the impact or effects that appear due to stress. He discovered that the factors triggering the emergence of stress were due to demands and high work pressure; work overload; the inter-personal relationship (including disputes with colleagues); buildup of work; overtime; disagreements among the leadership; lack of appreciation from superiors; the complexity of the work; the lack of help from colleagues and superiors; and the discipline of the time.

\subsection{Work-Family Conflict}

Ahmad, Muazzam, Anjum, Visvizi, and Nawaz (2020) stated that work and family are two essential spheres of one's life, and they cannot be separated. Work is not only an essential source of income but also, ideally, a source of positive stimuli for one's self-esteem, empowerment, etc. Family, ideally, should be the source of love, affection, and contentment. Ideally, therefore, keeping work and family simultaneously in balance will have positive effects on individuals' well-being. Furthermore, Tsionou and Konstantopoulos (2015) categorized the various outcomes produced by the relationship between work and family. In other words, this review article assesses the consequences of the work-family interface through the perspective of conflict and facilitation, as argued in previous research.

Work-life conflict impact on organizational outcomes as a result of employees experiencing decreased employee job satisfaction, increased staff turnover and absenteeism, lower performance and increased job stress levels, and intention to leave the organization (Majekodunmi, 2017; Rose, Hunt, \& Ayers, 2007). Furthermore, Majekodunmi (2017) discovered that work-family-conflict was more predominant with working mother than the family-workconflict. There was a positive significant relationship between work-family-conflict; family-work-conflict and job performance of working mothers.

In another context, Ahmad (2008) developed a model on predictors of work-family conflict which suggests that the predictors could be job-related (job type, work time commitment, job involvement, role overload, job flexibility), family-related (number of children, life-cycle stage, family involvement, child care arrangements) and individualrelated (life role values, gender role orientation, locus of control, perfectionism). This present model is based on the stress-strain model (Dunham, 1984) whereby the predictors are referred to as stressors and the conflict as strain.

\subsection{Organizational Support}

Organizational support was based on organizational support theory, refers to the extent to which employees deem that their organization values their contribution and cares about their wellbeing (Abou-Moghli, 2015). Organizational support can generate a felt obligation to care about the organization's welfare and to help the organization accomplish its goal (Abou-Moghli, 2015; Eisenberger, Armeli, Rexwinkel, Lynch, \& Rhoades, 2001). Moreover, the role of organizational support through its dimensions: (organizational equity, leader's behavior supporting subordinates, and participation in decision making), in improving employees' performance (AbouMoghli, 2015).

Rozaini, Norailis, and Aida (2015) examined the relationship between quality of work-life and organizational support in the insurance industry. They discovered that organizations are continuously looking for new ways of doing business to meet the challenges of today's dynamic business environment. Given the amount of time and energy people expend at the workplace, workers need to satisfy their entire life. Workers perceived different aspects of the treatment would influence. Organizational support is defined as the extent to which workers perceive that the 
organization values their contributions and cares about their wellbeing. This is a key factor in influencing worker commitment to the organization, job satisfaction, and general quality of work life.

\subsection{Research Framework}

Figure 1 illustrates the research framework that associates work stress, work-family conflict, work performance, and organizational support whereby work stress and work-family conflict are the independent variables that associated with the dependent variable, namely work performance. Meanwhile, the organizational support is the mediating variable in consideration between the independent variables and the dependent variable.

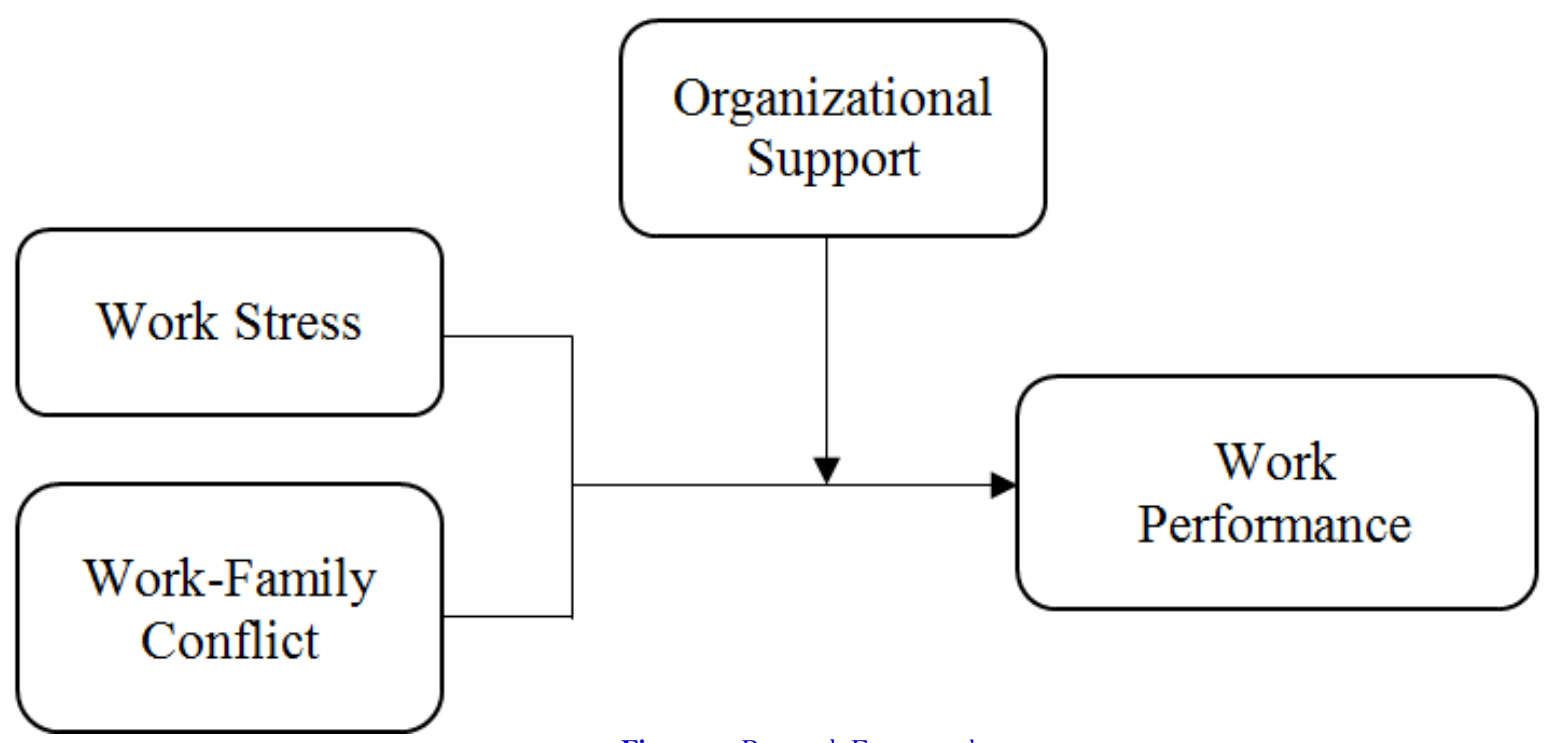

Figure-1. Research Framework.

\subsection{Hypotheses}

The hypotheses of this study are listed below based on the research framework on work stress, work-family conflict, work performance, and organizational support:

$H_{1}$ : Work stress has a positive impact on work performance among employees in the public and private organizations.

$H_{2}$ : Work-family conflict has a positive impact on work performance among employees in the public and private organizations.

$H_{s}$ : Organizational support has a mediation effect between work stress and work-family conflict toward work performance employees in the public and private organizations.

\section{METHODOLOGY}

A total of 600 self-administered questionnaires were distributed through e-mail to potential distance education students of Universiti Sains Malaysia. The self-administered questionnaires inquired on the adult student's involvement as the COVID-19 frontliners during the few phases of the Movement Control Order (MCO) and Conditional Movement Control Order (CMCO).

The MCOs and CMCO had been imposed by the government as below:

i. MCO1: 17-31 March 2020 (14 days).

ii. MCO2: 1-14 April 2020 (14 days).

iii. MCO3: 15-28 April 2020 (14 days).

iv. MCO4: 19 April-12 May 2020 (14 days).

v. CMCO: 13 May 2020 until 9 June 2020 (28 days). 


\subsection{Research Tools}

The self-administered questionnaires comprised of questions on work stress, work-family conflict, work performance, and organizational support. The tool was adapted and adopted by $\mathrm{Wu}, \mathrm{Wu}, \mathrm{Li}$, and Dan (2018). The tool comprised of 9 questions on work stress, 6 questions on work-family conflict, 6 questions on work performance, and 6 questions on organizational support. The Cronbach alpha of the tools ranged from 0.942 to 0.964 which is excellent.

\section{DATA ANALYSIS}

The data analyses were done based on the return of 316 self-administered questionnaires. Thus, this gave a response rate of $52.7 \%$. In this section, demographic analysis, reliability analysis, correlations analysis, and regression analysis were conducted.

\subsection{Demographic Analysis}

The demographic analyses were done on the respondents' gender, marital status, academic program, academic year, working sector, frontliners' status, and employer as depicted in Table 1. Male and female respondents were almost similar in distribution. Male were 136 respondents (43\%) against female were 180 respondents (57\%). Based on marital status, married respondents were $110(34.8 \%)$, single respondents were 71 (22.5\%), and divorced respondents were $5(1.6 \%)$.

Majority of the respondents were working in the public sector $(\mathrm{n}=225,71.2 \%)$ as compared to the respondents in the private sector $(\mathrm{n}=83,26.3 \%)$. Interestingly, 148 respondents (46.8\%) were classified as frontliners as compared to non-frontliners 166 respondents (52.5\%). The frontliners were working with Police Department (Polis DiRaja Malaysia [PDRM]), Military (Angkatan Tentera Malaysia [ATM]), Maritime Department (Angkatan Pertahanan Maritim Malaysia [APMM]), Customs Department, Immigration Department, and Fire \& Rescue Department. Furthermore demographically, 63 respondents (19.9\%) were police personnel, 26 respondents (8.2\%) were in the health personnel, 14 respondents (4.4\%) were customs personnel, 12 respondents $(3.8 \%)$ were the maritime personnel, 7 respondents (2.2\%) were fire \& rescue personnel, and 6 respondents (1.9\%) were military.

Respondents were inquired on their academic program, namely Science, Social Sciences, Humanities, and Management. Firstly, the Management Department had 200 respondents (63.3\%). Secondly, the Science Department had 4 academic programs, namely Biology, Chemistry, Physics, and Mathematics. Furthermore, Biology had 17 respondents (5.4\%) and Physics had 7 respondents (2.2\%). Meanwhile, Chemistry and Mathematics had 2 respondents $(0.6 \%)$, respectively. Thirdly the Social Sciences Department had 3 academic programs, namely Political Science, Economics, and Anthropology-Sociology. Political Science had 23 respondents (7.3\%), Anthropology-Sociology had 22 respondents (7\%), and Economics had 3 respondents (0.9\%). Finally, the Humanities Department had 3 academic programs, namely Geography, History, and Literature. Geography had 16 respondents (5.1\%), History had 15 respondents (4.7\%), and Literature had 9 respondents (2.8\%).

Majority of the respondents were in the Year $3(n=106,33.5 \%)$ as compared to 71 respondents $(22.5 \%)$ were in the Year 4, 50 respondents (15.8\%) were in the Year 1, 34 respondents (10.8\%) were in the Year 5 , and 17 respondents (5.4\%) were in the Year 2. Finally, 35 respondents (11.1\%) were alumni.

\subsection{Reliability Analysis}

The tools' reliability analysis was examined. Interestingly, all of the items were above 0.70 in Cronbach's Alpha value. Table 2 depicts the reliability analysis for work stress for 9 items $(\alpha=0.90)$, work-family conflict for 6 items $(\alpha=0.81)$, work performance for 6 items $(\alpha=0.92)$, and organizational support for 5 items $(\alpha=0.87)$. 
Table-1. Demographic analysis.

\begin{tabular}{|c|c|c|}
\hline Item & $\mathbf{n}$ & $\%$ \\
\hline \multicolumn{3}{|l|}{ Gender } \\
\hline - $\quad$ Male & 136 & 43 \\
\hline - $\quad$ Female & 180 & 57 \\
\hline \multicolumn{3}{|l|}{ Marital Status } \\
\hline - $\quad$ Married & 110 & 34.8 \\
\hline - $\quad$ Single & 71 & 22.5 \\
\hline - $\quad$ Others & 5 & 1.6 \\
\hline \multicolumn{3}{|l|}{ Academic Program } \\
\hline - $\quad$ Biology & 17 & 5.4 \\
\hline - $\quad$ Chemistry & 2 & 0.6 \\
\hline - $\quad$ Physics & 7 & 2.2 \\
\hline - $\quad$ Mathematics & 2 & 0.6 \\
\hline - $\quad$ Political Science & 23 & 7.3 \\
\hline - $\quad$ Economics & 3 & 0.9 \\
\hline - $\quad$ Anthropology-Sociology & 22 & 7 \\
\hline - Geography & 16 & 5.1 \\
\hline - History & 15 & 4.7 \\
\hline - $\quad$ Literature & 9 & 2.8 \\
\hline - $\quad$ Management & 200 & 63.3 \\
\hline \multicolumn{3}{|l|}{ Academic Year } \\
\hline - $\quad$ Year 1 & 50 & 15.8 \\
\hline - $\quad$ Year 2 & 17 & 5.4 \\
\hline - $\quad$ Year 3 & 106 & 33.5 \\
\hline - $\quad$ Year 4 & 71 & 22.5 \\
\hline - $\quad$ Year 5 & 34 & 10.8 \\
\hline - $\quad$ Alumni & 35 & 11.1 \\
\hline \multicolumn{3}{|l|}{ Working Sector } \\
\hline - $\quad$ Public Sector & 225 & 71.2 \\
\hline - $\quad$ Private Sector & 83 & 26.3 \\
\hline - $\quad$ Others & 7 & 2.2 \\
\hline \multicolumn{3}{|l|}{ Frontliners Status } \\
\hline - $\quad$ Yes & 148 & 46.8 \\
\hline - $\mathrm{No}$ & 166 & 52.5 \\
\hline \multicolumn{3}{|l|}{ Employment } \\
\hline - $\quad$ Police (PDRM) & 63 & 19.9 \\
\hline - $\quad$ Military (ATM) & 6 & 1.9 \\
\hline - $\quad$ Health (KKM) & 26 & 8.2 \\
\hline - $\quad$ Maritime (APMM) & 12 & 3.8 \\
\hline - Customs & 14 & 4.4 \\
\hline - Immigration & 10 & 3.2 \\
\hline - $\quad$ Fire \& Rescue & 7 & 2.2 \\
\hline - $\quad$ Prison & 8 & 2.5 \\
\hline - $\quad$ Port & 2 & 0.6 \\
\hline - $\quad$ Oil \& Gas & 2 & 0.6 \\
\hline - Disaster Management Office & 1 & 0.3 \\
\hline - $\quad$ Agriculture \& Fisheries & 10 & 3.2 \\
\hline - Higher Education & 8 & 2.5 \\
\hline - $\quad$ Consumer Agency (KPDNHEP) & 1 & 0.3 \\
\hline - $\quad$ State Office & 1 & 0.3 \\
\hline - $\quad$ Airlines & 1 & 0.3 \\
\hline - $\quad$ Education & 17 & 5.4 \\
\hline - $\quad$ Banking \& Finance & 11 & 3.5 \\
\hline
\end{tabular}




\begin{tabular}{cl|c|c}
\hline$\bullet$ & Drug Agency (AADK) & 6 & 1.9 \\
\hline$\bullet$ & Home Security (RELA) & 2 & 0.6 \\
\hline$\bullet$ & Legal \& Courts & 7 & 2.2 \\
\hline$\bullet$ & Telecommunication & 6 & 1.9 \\
\hline$\bullet$ & Corruption Agency (SPRM) & 4 & 1.3 \\
\hline$\bullet$ & Manufacturing & 8 & 2.5 \\
\hline$\bullet$ & Business & 4 & 1.3 \\
\hline$\bullet$ & Employee Provident Fund (EPF) & 2 & 0.6 \\
\hline$\bullet$ & Taxation Agency (LHDN) & 2 & 0.6 \\
\hline$\bullet$ & Construction & 3 & 0.9 \\
\hline$\bullet$ & Local Government & 1 & 0.3 \\
\hline$\bullet$ & Safety \& Security & 2 & 0.6 \\
\hline$\bullet$ & Museum & 1 & 0.3 \\
\hline$\bullet$ & Information Technology & 1 & 0.3 \\
\hline$\bullet$ & Technician & 2 & 0.6 \\
\hline$\bullet$ & Tourism & 1 & 0.3 \\
\hline$\bullet$ & Veterinary Office & 1 & 0.3 \\
\hline$\bullet$ & Religious Department & 2 & 0.6 \\
\hline$\bullet$ & Logistics & 2 & 0.6 \\
\hline$\bullet$ & Wildlife & 0.3 \\
\hline$\bullet$ & Others & 12.3 \\
\hline$\bullet$ & Unemployed & 0.6 \\
\hline
\end{tabular}

Table-2. Reliability Analysis.

\begin{tabular}{l|c|c}
\hline Items & n & Cronbach's Alpha \\
\hline Work Stress & 9 & 0.90 \\
\hline Work-Family Conflict & 6 & 0.81 \\
\hline Work Performance & 6 & 0.92 \\
\hline Organizational Support & 5 & 0.87 \\
\hline
\end{tabular}

\subsection{Correlations Analysis}

The correlations analysis had indicated that all items were having a significant relationship among components at the levels of 0.01 ( 4 items) and 0.05 ( 2 items). Table 3 depicts that high relationship was between work stress and work-family conflict $(\mathrm{r}=0.61)$ and work performance and organizational support $(\mathrm{r}=0.51)$.

On the other hand, several negative negligible relationships were discovered among items. Firstly, work performance had a negative low relationship with work stress ( $\mathrm{r}=-0.13$ )and work-family conflict $(\mathrm{r}=-0.13)$; and followed by organizational support with a negative relationship with work stress $(\mathrm{r}=-0.27)$ and work-family conflict $(\mathrm{r}=-0.15)$.

Table-3. Correlations Analysis.

\begin{tabular}{l|c|c|c|c}
\hline Items & $\mathbf{1}$ & $\mathbf{2}$ & $\mathbf{3}$ & $\mathbf{4}$ \\
\hline 1. Work Stress & 1 & $0.61^{* *}$ & $-0.13^{*}$ & $-0.27^{* *}$ \\
\hline 2. Work-Family Conflict & & 1 & $-0.13^{*}$ & $-0.15^{* *}$ \\
\hline 3. Work Performance & & & 1 & $0.51^{* *}$ \\
\hline 4. Organizational Support & & & & 1 \\
\hline Note: \\
**. Correlation is significant at the 0.01 level (2-tailed). \\
*. Correlation is significant at the 0.05 level (2-tailed).
\end{tabular}

\subsection{Regression Analysis}

Table 4 depicts the regression analysis was conducted on work performance toward work stress. The respondents had the $\mathrm{R}^{2}$ value showed $13 \%$ for the dependent variable of work performance, which was explained by the work stress $(\beta=-0.13, \mathrm{p}<0.05)$. The regression analysis indicated that $87 \%$ of the variance for work performance 
was explained by other unknown additional variables that have not been explored. Furthermore, the regression model $(\mathrm{F}=5.29, \mathrm{p}<0.05)$ was proven to be a significant model due to the $\mathrm{F}$ ratio being significant in predicting work performance. In conclusion, work stress was significant in predicting work performance among respondents. Thus, hypotheses $\mathrm{H}_{1}$ was supported in explaining the respondents on their work stress toward work performance.

\begin{tabular}{l|c|c}
\multirow{2}{*}{ Table-4. Regression analysis of work stress and toward work performance. } \\
\cline { 2 - 3 } & \multicolumn{3}{|c}{ Work Performance } \\
\cline { 2 - 3 } & $\boldsymbol{\beta}$ & Sig. \\
\hline $\mathrm{R}$ & -0.130 & 0.022 \\
\hline $\mathrm{R}^{2}$ & \multicolumn{2}{|c}{0.130} \\
\hline F Change & \multicolumn{2}{|c}{0.017} \\
\hline Sig. F Change & \multicolumn{2}{|c}{5.289} \\
\hline
\end{tabular}

Table 5 depicts the regression analysis was conducted on work performance toward work-family conflict. The respondents had the $\mathrm{R}^{2}$ value showed $12.7 \%$ for the dependent variable of work performance, which was explained by the work-family conflict $(\beta=-0.13, \mathrm{p}<0.05)$. The regression analysis indicated that $87.3 \%$ of the variance for work performance was explained by other unknown additional variables that have not been explored. Furthermore, the regression model $(\mathrm{F}=5.02, \mathrm{p}<0.05)$ was proven to be a significant model due to the $\mathrm{F}$ ratio being significant in predicting work performance. In conclusion, the work-family conflict was significant in predicting work performance among respondents. Thus, hypotheses $\mathrm{H}_{2}$ was supported in explaining the respondents on their workfamily conflict toward work performance.

Table-5. Regression analysis of work-family conflict toward work performance.

\begin{tabular}{l|c|c}
\hline \multirow{2}{*}{ Work-Family Conflict } & \multicolumn{2}{|c}{ Work Performance } \\
\cline { 2 - 3 } & $\boldsymbol{\beta}$ & Sig. \\
\cline { 2 - 3 } $\mathrm{R}$ & -0.127 & 0.026 \\
\hline $\mathrm{R}^{2}$ & \multicolumn{2}{|c}{0.127} \\
\hline F Change & \multicolumn{2}{|c}{0.016} \\
\hline Sig. F Change & \multicolumn{2}{|c}{5.015} \\
\hline
\end{tabular}

\subsection{Mediation Analysis}

Table 6 depicts the mediation analysis of organizational support between work stress and work-family conflict toward work performance. The first analysis, Model 1, without the mediation of organizational support among respondents, indicated that the $\mathrm{R}^{2}$ value showed $14.3 \%$ for the work performance, which was explained by the work stress $(\beta=-0.08, p>0.05)$ and work-family conflict $(\beta=-0.07, p>0.05)$ without the mediation of organizational support. Furthermore, the regression analysis without the mediation of organizational support indicated that $85.7 \%$ of the variance for work performance was explained by other unknown additional variables that have not been explored. The regression model $(\mathrm{F}=3.17, \mathrm{p}<0.05)$ was proven to be a significant model due to the $\mathrm{F}$ ratio being significant in predicting work performance.

The second analysis, Model 2, with the mediation of organizational support among respondents, indicated that the $\mathrm{R}^{2}$ value showed $51.8 \%$ for the work performance, which was explained by the work stress $(\beta=0.06, \mathrm{p}>0.05)$ and work-family conflict $(\beta=-0.09, p>0.05)$ with the mediation of organizational support. Furthermore, the regression analysis with the mediation of organizational support indicated that $48.2 \%$ of the variance for work performance was explained by other unknown additional variables that have not been explored. The regression model $(\mathrm{F}=102.1$, $\mathrm{p}<0.05)$ was proven to be a significant model due to the $\mathrm{F}$ ratio being significant in predicting work performance.

In conclusion, the mediation variables, namely organizational support, was significant in predicting the work stress and work-family conflict toward work performance among respondents. Thus, H3 was supported that 
organizational support mediates the impacts of work stress and work-family conflict toward work performance among respondents.

Table-6. Mediation of organizational support on the regression between work stress and work-family conflict toward work performance.

\begin{tabular}{|c|c|c|c|c|}
\hline \multirow{4}{*}{ Work Stress } & \multicolumn{2}{|c|}{ Model 1 Without Mediation } & \multicolumn{2}{|c|}{ Model 2 With Mediation } \\
\hline & \multicolumn{4}{|c|}{ Work Performance } \\
\hline & $\boldsymbol{\beta}$ & Sig. & $\boldsymbol{\beta}$ & Sig. \\
\hline & -0.084 & 0.240 & 0.063 & 0.322 \\
\hline Work-Family Conflict & -0.075 & 0.295 & -0.087 & 0.164 \\
\hline Organizational Support & - & - & 0.518 & 0.000 \\
\hline $\mathrm{R}$ & \multicolumn{2}{|c|}{0.143} & \multicolumn{2}{|c|}{0.518} \\
\hline $\mathrm{R}^{2}$ & \multicolumn{2}{|c|}{0.021} & \multicolumn{2}{|c|}{0.269} \\
\hline F Change & \multicolumn{2}{|c|}{3.170} & \multicolumn{2}{|c|}{102.101} \\
\hline Sig. F Change & \multicolumn{2}{|c|}{0.043} & \multicolumn{2}{|c|}{0.000} \\
\hline
\end{tabular}

\section{DISCUSSIONS \& CONCLUSION}

Employees in the public and private organizations indicate that their work performance has a positive relationship with their organizational support during the pandemic. This has been explained by the strong level of relationship between work performance and organizational support. On the setback, the employees have indicated that their work stress has a high relationship with their work-family conflict. As such during the pandemic, the employees indicated that they need to balance their work stress as not to affect their relationship with their spouse and family members. Similarly, the employees also had to balance their work-family conflict at home as not to affect their working environment that leads to the level of work stress. Moreover, the employees' work performance is affected by the low level of work stress at work and work-family conflict at home. Therefore, if the employees can manage their level of work stress at work, then this will improve their level of work performance. At this juncture, the involvement by the organizations on their organizational support will help their employees to level down their work stress that will lead to level up on their work performance. Moreover, if the employees are facing issues of work-family conflict at home, then this situation will impact their work performance at the organizations. Thus, this situation will lead to a low level of work performance due to issues at home.

The employees indicate their work performance has an impact on their work performance. Although the value of impact is negative, it reveals vividly that at the employees reduce their work stress, then their work performance will increase. Thus, the organizations need to extend their organizational support to mitigate their employees' work stress as this will lead to their work performance for the organization. Similarly, the employees need to mitigate their work-family conflict, if any, from affecting their work performance. Moreover, the organizations could provide organizational support through having an appointed family counsellor at their workplace or refer them to the relevant agencies or authorities to resolve the employees' work-family conflict. Thus, the employees need to eliminate their work-family conflict at home from affecting their work performance at work for the benefit of the organizations.

The employees perceived organizational support as a positive factor in their work performance. The employees indicate that organizational support mediates their work stress and work-family conflict toward their work performance. Thus, the organizations need to have and portray their organization's organizational support to be made ready and available toward their employees.

The world may not free from the COVID-19 pandemic. This says goes also to the country. The country must handle the pandemic amicably toward reviving the nation's businesses and economies. Moreover, the country cannot have another wave of COVID-19 pandemic that may impact the nation's business and economies. Government agencies and departments must work in hand with the organizations in working on the nations' interests. 
Moreover, the employees of the organizations need to feel their organizational support in mitigating their work stress and work-family conflict during the COVID-19 pandemic. The mitigation through the mediation of organizational support will give a positive impact to the employees' work performance and definitely will reflect on the organizations' profits that will help the nation to revive its businesses and economies.

Funding: The authors would like to thank you the Universiti Sains Malaysia for the funding and research grant support. Ref. No: 1001/PJJAUH/8016077.

Competing Interests: The authors declare that they have no competing interests.

Acknowledgement: All authors contributed equally to the conception and design of the study.

\section{REFERENCES}

Abou-Moghli, A. (2015). The role of organizational support in improving employees performance. International Business Research, 8(2), 198-203.Available at: http://dx.doi.org/10.5539/ibr.v8n2p198.

Ahmad, A. (2008). Job, family and individual factors as predictors of work-family conflict. The Journal of Human Resource and Adult Learning, 4(1), 57-65.

Ahmad, M., Muazzam, A., Anjum, A., Visvizi, A., \& Nawaz, R. (2020). Linking work-family conflict (WFC) and talent management: Insights from a developing country. Sustainability, 12, 2861-2877.Available at: 10.3390/su 12072861.

Al-Omari, K., \& Okasheh, H. (2017). The influence of work environment on job performance: A case study of engineering company in Jordan. International Journal of Applied Engineering Research, 12(24), 15544-15550.

Amjad, A., A., Li, Z. B., Huang, J. P., \& Ali, Z. (2016). The impact of motivation on the employee performance and job satisfaction in it park (Software House) sector of Peshawar, Pakistan. International Journal of Academic Research in Business and Social Sciences, 6(9), 297-3 10.Available at: http://dx.doi.org/10.6007/IJARBSS/v6-i9/2311.

Bevan, S. (2012). Good work, high performance and productivity. Paper presented at the The Paper Prepared for the European HRD Forume, Lisbon, 2012.

Blaug, R., Kenyon, A., \& Lekhi, R. (2007). Stress at work. London: The Work Foundation.

Conwaya, P. M., Campaninia, P., Sartoria, S., Dottib, R., \& Costaa, G. (2008). Main and interactive effects of shiftwork, a ge and work stress on health in an italian sample of healthcare workers. Applied Ergonomics, 39, 630-639.Available at: http://dx.doi.org/10.1016/j.apergo.2008.01.007.

Dahkoul, Z. M. (2018). The determinants of employee performance in jordanian organizations. Journal of Economics, Finance and Accounting, 5(1), 11-17.Available at: http://doi.org/10.17261/Pressacademia.2018.780.

Dunham, R. B. (1984). Organizational behavior. Illinois: Richard D. Irwin, Inc.

Eisenberger, R., Armeli, S., Rexwinkel, B., Lynch, P. D., \& Rhoades, L. (2001). Reciprocation of perceived organizational support. Journal of Applied Psychology, 86, 42-51.Available at: 10.1037//002 1-9010.86.1.42.

Ellinger, A. D., Ellinger, A. E., \& Keller, S. B. (2003 ). Supervisory coaching behavior, employee satisfaction and warehouse employee performance: A dyadic perspective in the distribution industry. Human Resource Development Quarterly, 14(4), $435-458$.

Gitongu, M. K., Kingi, W., \& Uzel, J. M. M. (2016). Determinants of employees' performance of State Parastatals in Kenya: Kenya ports authority. International Journal of Humanities and Social Science 6(10), 197-204.

Harter, J. K., Schmidt, F. L., \& Keyes, C. L. (2002). Well-being in the workplace and its relationship to business Outcomes: A review of the gallup studie. In C.L. Keyes \& J. Haidt (Eds.), Flourishing: The Positive Person and the Good Life (pp. 205-224). Washington D.C.: American Psychological Association.

Kusuma, W. A. (2018). Work stress (Causes, Impacts and Solutions): A case study on the net. Yogyakarta Employees. Russian Journal of Agricultural and Socio-Economic Sciences, 4(76), 80-91.Available at: https://doi.org/10.18551/rjoas.201804.09.

Landy, F. J. (1985). Psychology of work behavior. Chicago, IL: The Dorsey Press.

Lu, L. (1997). The process of work stress: A dialogue between theory and research. Chinese Journal of Mental Health, 1O(1), 19-51. 
Mackay, C. J., Cousins, R., Kell, P. J., Lee, S., \& McCaig, R. H. (2004). Management standards and work-related stress in the UK: Policy background and science. Work \& Stress, 18(2), 91-112.

Mai, K. N., \& Yen, V. H. (2016). Investigate the effects of job stress on employee job performance--a case study at Dong Xuyen industrial zone, Vietnam. International Journal of Trade, Economics and Finance, 7(2), 31-37.Available at: http://doi.org/10.18178/ijtef.2016.7.2.495.

Majekodunmi, A. E. (2017). Work-family-conflict and family-work-conflict as correlates of job performance among working mothers: Implications for industrial social workers. African Journal of Social Work, 7(1), 52-62.

Mizuno, M., Yamada, Y., Ishii, A., \& Tanaka, S. (2006). A human resource management approach to motivation and job stress in paramedics. Paper presented at the International Congress Series.

Muda, I., Rafiki, A., \& Harahap, M. R. (2014). Factors influencing employees' performance: A study on the islamic banks in Indonesia. International Journal of Business and Social Science, 5(2), 73-80.

Prajogo, D. I. (2007). The relationship between competitive strategies and product quality. Industrial Management and Data Systems, 107(1), 69-83.Available at: http://dx.doi.org/10.1108/0263557071071906.

Prime Minister's Office of Malaysia. (2020a). PRIHATIN economic stimulus package. Retrieved from: https://www.pmo.gov.my/prihatin-economic-stimulus-package/. [Accessed 7 August 2020].

Prime Minister's Office of Malaysia. (2020b). PRIHATIN economic stimulus package. Retrieved from: https://www.pmo.gov.my/2020/07/economic-stimulus-packages-saved-2-75-million-jobs-pm-muhyiddin/. [Accessed 7 August 2020].

Rose, S., Hunt, T., \& Ayers, B. (2007). Adjust the balance: Literature review life cycles and work life balance. (Publication No.60163) [Master Thesis, Centre of health Psychology, Staffordshire University Stoke on Trent]. Retrieved from: http://essay.utwente.nl/60163/1/MA_thesis_K_Kupper.pdf.

Rozaini, R., Norailis, A., \& Aida, B. (2015). Roles of organizational support in quality of work life in insurance industry. Journal of Economics, Business and Management, 3(8), 753-757.

Tsionou, T., \& Konstantopoulos, N. (2015). The complications and challenges of the work-family interface: A review paper. Procedia-Social and Behavioral Sciences, 175, 593-600.

Wong, W. P., \& Wong, K. Y. (2007). Supply chain performance measurement system using DEA modelling. Industrial Management and Data Systems, 107(3), 361-381.Available at: http://dx.doi.org/10.1108/02635570710734271.

World Health Organization. (2020). Novel coronavirus - China. Retrieved from: https://www.who.int/csr/don/12-january2020-novel-coronavirus-china/en/. [Accessed 6 August 2020].

Worldometer. (2020). COVID-19 coronavirus pandemic. Retrieved from: https://www.worldometers.info/coronavirus/. [Accessed 7 August 2020].

Wu, G., Wu, Y., Li, H., \& Dan, C. (2018). Job burnout, work-family conflict and project performance for construction professionals: The moderating role of organizational support. International Journal of Environmental Research and Public Health, 15(12), 2869. 